\title{
Pengembangan Instrumen Penilaian Kinerja untuk Mengukur Kemampuan Psikomotorik Siswa dalam Praktikum Laju Reaksi
}

\section{Development of Performance Assessment Instruments for Measuring Student Psychomotor Ability on The Reaction Rate Practicum}

\author{
Ade Irma Isnaini ${ }^{1}$, Lisa Utami ${ }^{1}$ \\ ${ }^{1}$ Program Studi Pendidikan Kimia Fakultas Tarbiyah dan Keguruan, Universitas Islam Negeri Sultan Syarif \\ Kasim Riau, Pekanbaru, Indonesia
}

\begin{abstract}
A B S T R A K
Penelitian ini bertujuan untuk mendesain instrumen penilaian kinerja dan uji coba penggunaan instrumen penilaian kinerja dalam mengukur kemampuan psikomotorik siswa pada parktikum laju reaksi. Metode penelitian yang digunakan yaitu mixed methods research dengan desain penelitian sekuensial eksploratori. Penelitian ini dilakukan secara bertahap (sekuensial) dimana peneliti terlebih dahulu memulai dengan mengeksplorasi data kualitatif dan menganalisisnya kemudian mengggunakan temuan pada fase kualitatif untuk mengembangkan instrumen dan menganalisis nya secara kuantitatif di kelas XI SMAN 2 Pekanbaru. Instrumen yang dihasilkan dapat digunakan untuk mengukur tingkat psikomotorik siswa pada saat melakukan praktikum laju reaksi. Berdasarkan hasil pengujian didapatkan hasil kemampuan psikomotorik siswa berdasarkan indikator sebesar 78,27 \% dengan kriteria baik. Hasil penelitian dari angket respon pengguna menunjukkan bahwa aspek materi dan konstruksi mendapatkan persentase tertinggi yaitu sebesar $100 \%$ dengan kategori sangat baik. Kemudian diikuti oleh aspek bahasa yang mendapatkan persentase 92\% dengan kategori sangat baik juga. Secara keseluruhan, rata-rata persentase angket respon pengguna yakni 97,33\% dengan kategori sangat baik. Hal ini menunjukkan bahwa instrumen penilaian kinerja yang dikembangkan peneliti sangat baik dalam mengukur kemampuan psikomotorik siswa pada pokok bahasan laju reaksi dan dapat digunakan oleh guru sebagai instrumen alternatif untuk mengukur kemampuan psikomotorik siswa dalam kegiatan praktikum.
\end{abstract}

\section{A B STRACT}

This research aimed to design the work assessment instrument and testing by using work assessment instrument to measure student psychomotor ability in Reaction rate practical work. It used mixed methods research with sequential exploratory design. It was done sequentially, in the beginning the researcher started by exploring the qualitative data and analyzing. Then, using the findings of qualitative phase to develop the instrument and analyze quantitatively at the $11^{\text {th }}$ grade of State $2^{\text {th }}$ Senior High School of Pekanbaru. This instrument was used to measure student psychomotor level in doing reaction rate practical work. The mean of student psychomotor ability based on the indicators was $78.27 \%$ and it was on good category. The research findings of user response questionnaire showed that the aspect of material and construction got the highest percentage, it was $100 \%$ and it was on very good category. Then, it was followed by the aspect of language that the percentage was $92 \%$, and it was on very good category. Overall, mean percentage of user response questionnaire was $97.33 \%$ and it was on very good category. It meant that the performance appraisal instrument developed by the researcher was very good to measure student psychomotor ability in Reaction rate lesson, and it could be used by the teachers as the appraisal instrument recommendation to measure student psychomotor ability in Reaction rate lesson.

Kata kunci : Kemampuan psikomotorik; laju raksi; pengembangan instrumen penilaian.

Keyword : Psychomotor ability; reaction rate; development of assesment instruments

I N F O A R T I K E L

Received: 11 Apr 2020;

Revised: 25 May 2020;

* coresponding author: adeirmaisnaini9@gmail.com

Accepted: 08 Jun 2020

DOI: https://doi.org/10.22437/jisic.v12i1.9054 


\section{PENDAHULUAN}

Pada hakikatnya ilmu kimia merupakan produk dan proses. Kimia sebagai produk meliputi sekumpulan pengetahuan kimia berupa fakta, konsep, prinsip, dan hukum. Kimia sebagai proses meliputi keterampilan-keterampilan yang disebut keterampilan proses dan sikap-sikap yang dimiliki oleh para ilmuan yang disebut sikap ilmiah. Salah satu bentuk proses pembelajaran kimia yang dapat mengakomodasi kedua hakikat ilmu kimia yaitu pembelajaran melalui kegiatan praktikum. Kegiatan praktikum dapat dipakai untuk mengembangkan keterampilan proses, membangkitkan minat belajar, dan memberikan bukti-bukti bagi kebenaran teori serta memudahkan siswa mempelajari konsep kimia yang abstrak (Ningtyas, 2014).

Beberapa permasalahan yang menyebabkan sulitnya siswa memperoleh hasil belajar yang baik pada mata pelajaran kimia antara lain, ilmu kimia banyak memiliki konsep-konsep yang abstrak, sehingga kimia cenderung tidak disukai dan sulit dipahami, serta kurangnya pelaksanaan praktikum kimia di sekolah (Darsana, 2014). Memang tidak semua sekolah memiliki laboratorium yang memadai untuk pengajaran praktikum yang mendukung pengajaran teori, namun sekolah yang telah memiliki laboratorium pun kadang-kadang belum memanfaatkan laboratorium dengan maksimal. Terdapat banyak faktor yang menyebabkan mengapa hal tersebut bisa terjadi, namun salah satunya adalah guru merasa bahwa sangat repot dan sulit mempersiapkan, melaksanakan, mengawasi dan menilai kegiatan praktikum yang dilaksanakan siswa di laboratorium sekolah.

Keterampilan kinerja yang dilakukan siswa pada saat melakukan praktikum merupakan suatu hal penting yang perlu dilaksanakan oleh siswa karena dapat meningkatkan keterampilan psikomotoriknya. Hal ini juga bisa dimanfaatkan untuk meningkatkan kemampuan penguasaan konseptual, seperti yang diungkapkan Kee bahwa demonstrasi atau praktik laboratorium lebih efektif daripada ceramah saja (Kee dalam Endang, 2015).

Penilaian hasil belajar peserta didik perlu dilakukan secara berkesinambungan agar perkembangan hasil belajarnya terpantau. Sistem penilaian di sekolah tertuang dalam Peraturan Menteri Pendidikan dan Kebudayaan Nomor 104 tahun 2014. Format penilaian dapat berupa tes tertulis, observasi, tes praktik dan penugasan perseorangan atau kelompok (Supahar \& Prasetyo, 2015).

Hal ini sesuai dengan Peraturan Pemerintah Nomor 19 Tahun 2005 pasal 63 ayat 1 salah satunya dilakukan oleh pendidik selain pemerintah dan satuan pendidikan itu sendiri. Kegiatan penilaian yang dilakukan oleh guru mencakup tiga ranah yaitu kognitif, afektif, dan psikomotorik. Ranah kognitif meliputi aspek yang berkaitan dengan kemampuan berpikir. Ranah afektif berdasarkan Krathwohl didefinisikan sebagai kegiatan yang berkaitan dengan sikap. Sedangkan aspek psikomotorik berkaitan dengan keterampilan fisik, motorik maupun tangan (Krathwohl dalam Yunita, 2016). Pada umumnya penilaian keterampilan dilakukan dengan cara mengamati pelaksanaan suatu tugas atau memeriksa produk yang dihasilkan oleh peserta didik. Kegiatan pengamatan dapat dipengaruhi oleh faktor subjektivitas sehingga diperlukan lembar pengamatan yang dilengkapi dengan pedoman penilaian yang relevan (Sani, 2016).

Penilaian yang digunakan oleh guru di Indonesia pada umumnya hanya menggunakan tes untuk mengukur aspek kognitif atau penguasaan pengetahuan peserta didik. Namun pada umumnya tes yang digunakan hanya mengukur kemampuan berpikir dalam tingkat kognitif yang rendah. Penilaian proses pembelajaran oleh guru juga perlu dilakukan dalam upaya mengetahui efektivitas program pembelajaran, memberikan umpan balik bagi peserta didik, memperbaiki program pembelajaran (Yunita, 2016). 
Guru telah terbiasa menggunakan penilaian hanya dengan menggunakan angka saja, sehingga penilaian secara kualitatif yang mencakup informasi tentang kelemahan dan kelebihan peserta didik sangat sulit dilakukan (Yunita, 2016). Salah satu instrumen penilaian yang sesuai dengan inti dari penilaian autentik dan dapat digunakan menilai keterampilan proses serta ketercapaian kompetensi dalam melakukan kegiatan praktikum di dalam melakukan kegiatan praktikum di laboratorium adalah penilaian kinerja.

Penilaian kinerja merupakan penilaian yang meminta peserta didik untuk mendemonstrasikan dan mengaplikasikan pengetahuan ke dalam konteks yang sesuai dengan kriteria yang ditetapkan. Lebih autentik dibanding dengan menggunakan tes klasik, dengan kata lain butir-butirnya lebih mencerminkan kemampuan yang diperlukan dalam praktik kehidupan sehari-hari. Instrumen kinerja yang baik harus tervalidasi oleh ahli materi dan guru kimia baik dari segi konstruksi, isi, dan kebahasaan sehingga penilaian kinerja memenuhi kinerja untuk menilai kinerja siswa yang meliputi kompetensi, keterampilan dan sikap.

Penilaian kinerja adalah penilaian yang di dalamnya guru mengamati dan membuat pertimbangan tentang keterampilan atau kompetensi siswa dalam melakukan suatu pekerjaan, menciptakan produk, serta melakukan presentasi. Penilaian kinerja merupakan wujud dari penilaian otentik, yaitu penilaian terhadap kemampuan atau cerminan kemampuan siswa melakukan tugas dalam situasi nyata (Firman, 2018).

Berdasarkan hasil wawancara terhadap guru kimia di SMAN 2 Pekanbaru, dapat diketahui bahwa materi laju reaksi khususnya pada faktor-faktor yang mempengaruhi laju reaksi diajarkan melalui metode praktikum. Guru menganggap dengan metode eksperimen atau praktikum memiliki pengaruh yang signifikan dalam hasil belajar. Siswa dapat lebih mudah memahami pembelajaran materi laju reaksi dengan menggunakan metode eksperimen. Penilaian praktikum yang dilakukan oleh guru yaitu pengamatan secara langsung dan menggunakan instrumen penilaian psikomotorik pada umumnya. Sedangkan dalam melakukan penilaian kinerja dibutuhkan instrumen yang tepat untuk mengukur keterampilan psikomotorik siswa sehingga penilaian kinerja dapat berlangsung lebih efektif dan objektif.

\section{METODE PENELITIAN}

Penelitian ini dilaksanakan di kelas XI SMAN 2 Pekanbaru Semester ganjil tahun ajaran 2018/2019. Populasi pada penelitian ini adalah seluruh siswa kelas XI SMAN 2 Pekanbaru tahun ajaran 2018/2019. Populasi dalam penelitian ini berjumlah 125 siswa dalam 4 kelas. Pengambilan sampel dilakukan dengan menggunakan teknik purposive sampling. Sampel pada penelitian ini berjumlah 36 siswa.

Metode penelitian yang digunakan pada penelitian ini merupakan metode campuran atau mix method dengan menggunakan desain penelitian sekuensial eksploratori.

Teknik pengumpulan data yang digunakan yaitu melalui observasi partisipasi, wawancara mendalam, dan dokumentasi.

Data yang terkumpul kemudian divalidasi kebenarannya menggunakan teknik triangulasi. Selanjutnya data diolah dan dianalisis menggunakan metode statistik deskriptif. Penentuan kriteria tiap aspek pada instrumen kemampuan psikomotor diperoleh dengan cara menginterpretasikan persentase tiap indikator yang didapat dari hasil pengolahan data ke dalam kriteria tertentu sesuai yang dikemukakan oleh riduwan (2011).

\section{HASIL DAN PEMBAHASAN}

Tujuan penelitian ini adalah menganalisis instrumen penilaian kerja aspek psikomotor pada materi laju reaksi dan mengetahui respon pengguna terhadap instrumen penilaian kerja tersebut. Instrumen 
penilaian yang dikembangkan berupa rubrik penilaian yang akan berguna sebagai panduan guru untuk melakukan penilaian secara otentik terhadap kinerja siswa dalam melakukan praktikum kimia, khususnya pada materi laju reaksi.

Temuan yang dihasilkan pada saat observasi lapangan dengan melakukan wawancara terhadap guru, didapatkan hasil bahwa dalam proses pembelajaran kimia khususnya pada materi faktor-faktor yang mempengaruhi laju reaksi dilakukan dengan menggunakan metode praktikum di laboratorium. Dan untuk penilaian psikomotorik guru menilai berdasarkan pengamatan keseharian dari siswa tersebut. Adanya kegiatan praktikum, tentunya memerlukan kegiatan evaluasi untuk menilai bagaimana kemampuan siswa dalam melakukan praktikum. Namun, kenyataannya penilaian yang dilakukan dalam kegiatan praktikum baru sebatas tes tertulis dan penilaian laporan praktikum. Rustaman dan Wulan mengungkapkan bahwa tes tertulis tidaklah cukup dalam menilai kemampuan siswa pada kegiatan praktikum. Kegiatan praktikum dapat digunakan untuk lebih memahami teori dan mengembangkan keterampilan dasar. Keterampilan dikembangkan melalui latihan menggunakan alat, mengobservasi, mengukur dan kegiatan lainnya (Maharomah, 2017).

Berdasarkan hasil wawancara terhadap siswa SMA kelas XI, didapatkan hasil bahwa metode praktikum mampu meningkatkan antusiasme siswa dalam pembelajaran. Dalam pelaksanaannya, kegiatan praktikum terbagi menjadi tahap persiapan, pelaksanaan, dan penutup. Setelah melakukan praktikum, salah satu kemampuan yang paling banyak didapatkan siswa yakni keterampilan dalam menggunakan alat-alat laboratorium. Dari hasil wawancara dapat diketahui bahwa metode praktikum yang diterapkan sarat akan kemampuan psikomotor serta mampu menarik perhatian siswa dalam belajar. Metode praktikum juga bertujuan untuk membekali siswa agar lebih dapat memahami teori dan praktik. Menurut Zainuddin melalui kegiatan praktikum, banyak hal yang dapat diperoleh oleh siswa diantaranya 1). Kegiatan praktikum dapat melatih keterampilan, 2). Memberi kesempatan kepada siswa untuk menerapkan dan mengintegrasikan pengetahuan dan keterampilan yang dimilikinya secara nyata dalam praktik, 3). Membuktikan sesuatu secara ilmiah/melakukan scientific inquiry, dan 4). Menghargai ilmu dan keterampilan inquiry (Mahmudatun, 2017).

Instrumen yang dibuat terdiri dari beberapa bagian, yaitu halaman sampul, kata pengantar, daftar isi, pendahuluan, petunjuk umum, penjelasan tentang penilaian kinerja, penjelasan psikomotorik, penjelasan materi, tata-tertib praktikum, petunjuk penggunaan, lembar kerja peserta didik, instrumen penilaian, dan pedoman penilaian. Instrumen yang disusun kemudian di validasi oleh tim ahli dan didapatkan hasil bahwa instrumen valid dan dapat digunakan dengan revisi. Selanjutnya instrumen ditinjau ulang oleh guru mata pelajaran kimia SMA dan beberapa saran yang diberikan ditindaklanjuti dengan melakukan revisi seperti penggunaan bahasa yang lebih baik lagi, serta penjelasan dalam petunjuk penggunaan instrumen agar lebih mudah untuk dimengerti.

Selanjutnya dilakukan uji coba terhadap 36 peserta didik kelas XI IPA 1 SMAN 2 Pekanbaru. Setelah data terkumpul, data tersebut dianalisis dengan menggunakan validasi item. validasi item berfungsi untuk memilih item mana saja yang layak dan item mana saja yang tidak layak digunakan untuk penelitian selanjutnya. Adapun cara analisis item adalah dengan cara mengkorelasikan skornya setiap item dengan skor totalnya dengan menggunakan rumus korelasi Product Moment dari Pearson.

Menurut Sugiyono bila harga koefesien korelasi dibawah 0,390, maka dapat disimpulkan bahwa instrumen tersebut tidak valid, sehingga harus diperbaiki atau dibuang. Merujuk pada pendapat tersebut maka item yang layak digunakan yaitu item yang korelasinya diatas 0,390. Sedangkan 
yang tidak layak digunakan korelasinya dibawah 0,390. Hasil analisis item instrumen kinerja dapat dilihat pada tabel 1 .

Tabel 1. Hasil analisis item instrumen penilaian kinerja

\begin{tabular}{ll}
\hline $\begin{array}{l}\text { Item yang layak } \\
\text { digunakan }\end{array}$ & $\begin{array}{l}\text { Item yang tidak } \\
\text { layak digunakan }\end{array}$ \\
\hline $1,2,3,4,5,6,7,9,10$, & $8,22,24$ \\
$11,12,13,14,15,16$, & \\
$17,18,19,20,21,23$ & \\
\hline
\end{tabular}

Berdasarkan tabel 1 dapat diketahui bahwa terdapat 21 item yang layak digunakan untuk penelitian selanjutnya. Sedangkan Item yang tidak layak digunakan akan dihapus dan tidak digunakan dalam penelitian selanjutnya.

Setelah melakukan analisis item maka selanjutnya dilakukan analisis rehabilitasi. Analisis reliabilitas dilakukan untuk menentukan apakah instrumen penilaian kinerja yang digunakan memiliki daya keajekan atau reliabilitas yang tinggi atau tidak. Hasil analisis reliabilitas dapat dilihat dalam tabel 2 berikut.

Tabel 2. Hasil analisis realiabilitas

\begin{tabular}{ll}
\hline Cronbach's Alpha & N of Items \\
\hline 0,734 & 21 \\
\hline
\end{tabular}

Hasil analisis reliabilitas 21 butir pada rubrik penilaian memiliki nilai Cronbach's Alpha sebesar 0,734>0,433. Sehingga dapat disimpulkan bahwa instrumen ini dapat dinyatakan telah memiliki reliabilitas yang tinggi. Data kemampuan psikomotorik siswa didapat dari hasil pengamatan terhadap 6 orang observer melalui lembar observasi yang telah dibuat. Data hasil observasi terlihat pada tabel 3 .

Tabel 3. Hasil Pengamatan Kemampuan Psikomotorik Siswa

\begin{tabular}{lc}
\hline Indikator Kemampuan Psikomotor & \% \\
\hline $\begin{array}{l}\text { Melakukan persiapan sebelum melakukan praktikum dan melakukan percobaan } \\
\text { sesuai dengan petunjuk praktikum. }\end{array}$ & 65,97 \\
$\begin{array}{l}\text { Keterampilan dalam menyiapkan bahan dan keterampilan dalam menggunakan } \\
\text { alat }\end{array}$ & 89,58 \\
$\begin{array}{l}\text { Menggambar hasil pengamatan } \\
\text { Melakukan persiapan sebelum melakukan praktikum dan melakukan percobaan }\end{array}$ & 74,07 \\
$\begin{array}{l}\text { Kesuai dengan petunjuk praktikum. } \\
\text { alat }\end{array}$ & 79,86 \\
Kemampuan dalam menciptakan, berinisiatif. & 82,22 \\
\hline \multicolumn{1}{c}{ Rata-rata } & 77,89 \\
\hline
\end{tabular}

Berdasarkan data pada tabel 3 menunjukkan bahwa persentase kemampuan psikomotorik siswa tiap indikator berbedabeda. Indikator dengan persentase tertinggi yaitu keterampilan dalam menyiapkan bahan dan keterampilan menggunakan alat sebesar $89,58 \%$ dengan kriteria sangat baik. Sedangkan indikator dengan persentase terendah sebesar $65,97 \%$ dengan kriteria baik adalah melakukan persiapan sebelum melakukan praktikum dan melakukan percobaan sesuai dengan petunjuk praktikum. Rata-rata indikator kemampuan psikomotorik siswa sebesar 78,27 \% dengan kriteria baik.

Instrumen penilaian kerja yang telah dikembangkan digunakan secara langsung sebagai alat evaluasi dalam proses 
pembelajaran. Penilaian dengan menggunakan instrumen penilaian kinerja tersebut dilakukan oleh observer yang mengamati kegiatan siswa selama kegiatan pembelajaran. Setelah pembelajaran selesai, observer kemudian diminta untuk mengisi angket respon pengguna.

Hasil pengisian angket respon pengguna oleh 6 orang observer yang bertindak sebagai responden dapat dilihat seperti pada gambar 1.

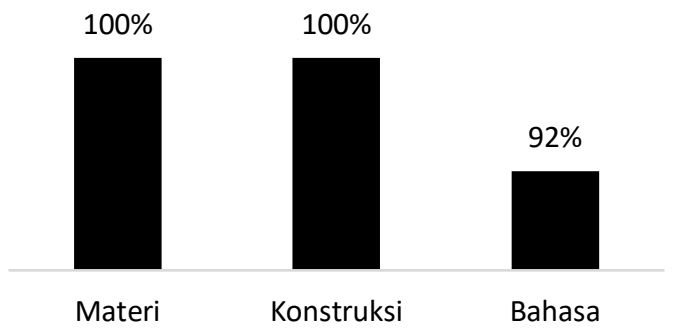

Gambar 1. Persentase respon pengguna terhadap kualitas instrumen penilaian kerja

Berdasarkan angket respon pengguna bahwa aspek materi dan konstruksi mendapatkan persentase tertinggi yaitu sebesar $100 \%$ dengan kategori sangat baik. Aspek materi mendapat persentase sebesar $100 \%$ menunjukkan bahwa instrumen penilaian sudah sesuai dengan tujuan pembelajaran. Dalam penyusunannya penetapan kisi-kisi instrumen penilaian didasarkan pada rumusan tujuan pembelajaran yang dihasilkan dari analisis kompetensi inti, kompetensi dasar, dan indikator.

Hal ini mengikuti pendapat Groundland yang menyatakan bahwa salah satu tujuan pembelajaran yakni sebagai dasar dalam menyusun alat penilaian hasil belajar. Sehingga instrumen yang dihasilkan bersifat relevan. Artinya, sesuai dengan kompetensi inti, kompetensi dasar, dan indikator yang telah ditetapkan. Pada aspek konstruksi menunjukkan bahwa instrumen penilaian telah memenuhi validitas konstruksi atau validitas susunan dimana butir-butir pada instrumen penilaian yang membangun instrumen benar-benar dapat dengan secara tepat mengukur aspek psikomotor sebagaimana telah ditentukan dalam tujuan instruksional khusus. Hal ini juga menunjukkan bahwa instrumen penilaian telah memenuhi kriteria kualitas rubrik yakni dapat memetakan kemampuan peserta didik Penelitian yang dilakukan Sela Marselyana Abadi juga menunjukkan hasil yang sama pada aspek konstruksi yakni termasuk ke dalam kategori sangat baik (Abadi, 2016).

Kemudian diikuti oleh aspek bahasa yang mendapatkan persentase $92 \%$ dengan kategori sangat baik juga. Hal ini menunjukkan bahwa penggunaan bahasa sudah sesuai dengan bahasa Indonesia yang baik dan benar dan menurut Ejaan Yang Disempurnakan (EYD) dan bersifat ringkas dan jelas. Hal ini dikarnakan dalam penyusunannya bahasa yang digunakan bukanlah bahasa yang digunakan sehari-hari dan berlaku setempat. Selain itu, penggunaan bahasa juga disesuaikan dengan tingkat perkembangan usia siswa sehingga bersifat komunikatif dan mudah dipahami. Hasil persentase pada aspek bahasa ini sejalan dengan penelitian yang dilakukan oleh Sela Marselyana Abadi dengan kategori sangat baik (Abadi, 2016).

\section{KESIMPULAN}

Berdasarkan dari hasil uji coba penggunaan instrumen penilaian kinerja menunjukkan rata-rata persentase respon dari pengguna yakni sebesar 97,33\% dengan kategori sangat baik. Aspek materi dan konstruksi mendapatkan persentase tertinggi yaitu sebesar $100 \%$ dengan kategori sangat baik. Kemudian diikuti oleh aspek bahasa yang mendapatkan persentase $92 \%$ dengan kategori sangat baik juga. Sehingga dapat disimpulkan bahwa instrumen penilaian kinerja yang dikembangkan sangat baik dalam mengukur kemampuan psikomotorik siswa pada pokok bahasan laju reaksi. 


\section{DAFTAR RUJUKAN}

Abadi, S.M. (2016). Pengembangan instrumen aspek psikomotorik siswa pada praktikum kimia pada materi termokimia, [Skripsi], Universitas Islam Negeri Syarif Hidayatullah Jakarta.

Sani, R. A. (2016). Penilaian autentik, Jakarta: Bumi Aksara.

Darsana, I. W., Sadia, I. W., \& Tika, I. Y. (2014). Analisis standar kebutuhan laboratorium kimia dalam implementasi kurikulum 2013 pada SMA Negeri kabupaten Bangli, Jurnal Pendidikan dan Pembelajaran IPA Indonesia, 4(1).

Endang, S. (2015). Analisis instrumen penilaian berbasis evaluasi otentik pada pengukuran keterampilan proses sains, Surabaya: UNS.

Firman, H. (2018). Assesmen pembelajaran kimia, Bandung: UPI.

Maharomah, N., Saptorini, \& Kasmui. (2017). Implementasi performance assessment terhadap aktivitas belajar siswa kelas xi melalui kegiatan praktikum, Chemistry in Education, 6(2), 42-28.

Nisa, U. M. (2017). Metode praktikum untuk meningkatkan pemahaman dan hasil belajar siswa kelas V MI YPPI 1945 Babat pada materi zat tunggal dan campuran, Proceeding Biology Education Conference, 14(1), 62-68.
Ningtyas, FK. (2014). Pengembangan instrumen penilaian kinerja siswa untuk mengakses keterampilan proses dalam praktikum senyawa polar dan nonpolar kelas $\mathrm{X}$ SMA, UNESA journal of chemical education, 3(3), 169.

Riduwan. (2011). Rumus dan data dalam aplikasi statiska, Bandung: Alfabeta.

Supahar \& Prasetyo, Z. K. (2015). Pengembangan instrumen penilaian kinerja kemampuan inkuiri peserta didik pada mata pelajaran fisika SMA, Jurnal Penelitian dan Evaluasi Pendidikan, 19(1), 97-98.

Sugiyono. (2017). Metode penelitian pendidikan pendekatan kualitatif, kuantitatif, dan $R \& D$, Bandung: Alfabeta.

Yunita, L., Agung, S., \& Nuraeni, R. (2016). Pengembangan instrumen penilaian aspek psikomotoik siswa SMA/MA pada praktikum asam basa. Prosiding Seminar Nasional Pendidikan IPA Pascasarjana UM, 1, 662-670. 